\title{
Regulatory Planning and Affordable Housing in Kigali City: Policies, Challenges and Prospects
}

\author{
Fred Nkubito ${ }^{1}$, and Andrew Baiden-Amissah ${ }^{2 *}$ \\ ${ }^{1,2}$ Department of Estate Management and Valuation, University of Rwanda-College of Science and Technology, \\ Kigali, Rwanda \\ $\underline{\text { abmissah@yahoo.com }}^{2 *}$, abaiden-amissah@ur.ac.rw ${ }^{2 *}$,fred.nkubito@gmail.com ${ }^{1}$
}

*Corresponding Author: Andrew Baiden-Amissah

\begin{abstract}
The availability of sufficient housing for all is often stated as a priority for enhancing the social needs of a society. Studies from elsewhere have suggested a correlation between zoning strictness and inflating housing costs, which also leads to the exclusion of social classes in cities. However, in Africa, these linkages have not been adequately assessed. With zoning being at the heart of the current planning system in Rwanda, this research aims at examining the linkages between zoning planning and housing affordability, in an emerging urban setting like Kigali City. The study employed a combination of systematic review of articles, policy documents, discourse, and cost analysis to assess the effects of the strictness of master plan and zoning requirements on housing costs, and the ease of access to housing particularly for low-income households. This paper finds a significant gap in affordable housing supply, a moderate impact of zoning regulations on housing production costs, and a clear policy determination to address the housing problem despite implementation constraints. This study thus suggests for a relaxation in zoning regulations for certain income thresholds, re-defining of affordability to match the local context, and the generation of housing affordability indexes to inform government's urban housing strategies.
\end{abstract}

Keywords: Regulatory Planning, Affordable Housing, Urban Poor Households, Kigali City

\section{Introduction}

Despite being widely regarded as a social merit (Leishman \& Rowley, 2012), access to housing remains a crucial challenge for a significant number of urban populations. According to UNHabitat (2016), about 881 million people currently live in slums in developing countries, and a further 1.6 billion people will face housing deficiencies by the year 2025. In line with the contributions of Sivam (2002), several other studies have suggested that, excessive land use restrictions may increase house prices and hence make it harder for urban communities with limited income, to access decent housing (Glaeser \& Gyourko, 2003; Harney, 2009; Monkkonen, 2013). Efforts to examine the link between the strictness of planning measures and the declining levels of housing affordability, should thus be enhanced (Lai \& Chung, 1994; Fischel, 1995; Lens \& Monkkonen, 2015) particularly for countries in the global south. 
In recent years, many developing countries have embarked on policy reforms which have given way to planning approaches mostly involving master plans and zoning regulations in attempts to control urbanization (UN-Habitat, 2009). These measures are hypothetically effective in reorganizing urban spaces into functional and segregated land uses, and also increased land productivity (Lai \& Chung, 1994; Fischel, 1995). They are thus considered as trusted tools against pressing urbanization challenges such as the proliferation of informal settlements and urban sprawl (Njoh, 1995). However, the fundamental problem with zoning regulations has been its tendency to exclude urban low-income communities through the imposition of minimum housing standards (Harney, 2009). In countries such as the United States of America where such principles are highly popularized, zoning has been associated to social exclusion and inflated cost of housing (Glaeser \& Gyourko, 2003; Ikeda \& Washington, 2015).

In Africa, most of the countries inherited their zoning systems from former colonial masters (Njoh, 1995; Njoh, 2003; Berrisford, 2014), while others received these policies through international exchanges between professionals, cities and the spread of planning practices that are dominated by western world perspective of a city (Nasr \& Volait, 2003; Gonzalez, 2011). In both cases, a major concern has been raised in terms of the mismatch between planning objectives and the underlying social and economic context, which in turn lead to negative outcomes (Watson, 2009a).

In Kigali City, master plan and zoning ordinances have been in operation since the year 2012, and these development frameworks drew inspiration from Singapore's urban development model (Shatkin, 2014). The City of Kigali considers strict land use regulation as a viable solution against spontaneous urban growth and efficient use of land. Nevertheless, the enforcement of the master planand zoning is hypothetically regarded as a major contributor to the shortages of affordable housing. As it was evidenced elsewhere, building compliance standards pertaining to height, density and amenities, zoning makes the overall building costs higher (Malpezzi \& Mayo 1997; Mayer \& Somerville 2000). Moreover, in the context of weak institutions, strict land use regulations can cause speculation and other market irregularities which in turn constrains new housing development (Mayo \& Angel, 1993; Biderman, 2008).

A considerable amount of scholarly work has disclosed a close link between the use of regulatoryplanning tools such as master plan and zoning ordinances and the subsequently high housing prices, and the spatial segregation of low-income urban communities (Lai \& Chung, 1994; Hui \& Ho, 2003). Most of the existing literature, however, examines this relationship with a focus on developed countries mostly North America, and Europe (Glaeser \& Gyourko, 2002; Leishman \& Rowley, 2012). On the basis of the foregoing, this paper seeks to respond and contribute to current debates on the interface between regulatory planning and the availability of affordable housing by examining the facilitations or constraints that are provided by the regulatory and policy frameworks, towards the provision of affordable housing; the nature and extent of affordable housing shortages in Kigali City, and the potential effects that the implementation of the master plan and zoning regulations may be having on housing costs. 


\section{Regulatory Planning Systems and Housing Affordability}

\subsection{Dimensions of Housing Affordability}

The subject of affordable housing has topped the agenda of many governments as they strive for alternative mechanisms to shelter their growing urban populations. Similarly, the increasing importance of affordable housing has attracted interests from many authors (Hulchanski, 1995; Stone, 2006; Gan \& Hill, 2009). However, the use of the concept could be ambiguous when it is aligned with diverse income groups (Stone, 2006). Affordability can be measured by a wide range of indicators. For instance, Quigley \& Raphael (2004) consider housing prices, housing quality, income distribution, household's credit worthiness, political and economic conditions affecting the supply of new housing, and households' choice on the amount to spend on housing vis-à-vis other consumption goods as essential indicators for measuring affordability.

Other studies consider affordability as the adequacy in quality and location of a house, which does not cost so much to prohibit its occupants meeting other basic living costs or threatens their enjoyment of basic human rights (UN-Habitat, 2011). To put this into a better perspective, Woetzel et al., (2014), opined that the cost of housing should not be more than 30 to 40 per cent of a household's income. In contrast, Smets et al., (2014), suggest the use of a housing expenditure-income ratio range of 25 to 30 per cent. The use of the housing costs to income ratio has attracted many critiques (Hulchanski, 1995; Stone, 2006), for reasons that the indicators used do not respond adequately to the true incidence of housing affordability problems (Leishman $\&$ Rowley, 2012). Furthermore, the apparent simplicity of the cost to income ratio (Hulchanski, 1995), makes it a 'rule of thumb', hence its validity is limited (Stone, 2006).

Against this background, the UN-Habitat (2011) suggests that affordability should be expressed in terms of a broad range of inputs affecting purchase cost and the ability to finance the purchase rather than being a simple conception of housing costs over income. It should also be noted that, affordability is affected by both capital variables such as cost of infrastructure, land, labor and access to finance and occupational variables like land leases, net housing expenditure and interest rates on mortgages, which are not adequately captured in the traditional expenditureincome ratio method (UN-Habitat, 2011).

Consequently, more rigorous methods to measure affordability have been recommended such as residual income assessment and incremental affordability (Smets et al., 2014). In other words, affordability should be considered as a households' ability to meet expenses for decent housing in accordance with the locally accepted standards without affecting their routine capacity to meet their non-housing needs. This paper thus, advances the issue of housing affordability by focusing on indicators such as housing quality, household income, and housing costs.

\subsection{Regulatory Planning Systems}

Also known as 'master planning' or 'zoning-based planning', regulatory planning often involves the production of plans providing detailed outlook of the urban fabric and the envisioned future of a city under different types of plans (UN-Habitat, 2009). These plans are primarily enforced through legally binding ordinances (Healey \& Williams, 1993) that give right to property owners 
to develop land according to plans and building standards. Thus, planning decisions are taken in the form of legal acts (Booth,1995).

In recent years, many countries have based their admiration for regulatory planning principles such as master plan and zoning on different experiences, to ensure that urban form is shaped by a concern for aesthetics, efficiency, and modernization (Watson 2009b; Lai \& Chung, 1994). For example, Singapore values these principles on the basis of ensuring efficient allocation of scarce land resources (Goldblum, 2008), whereas Rwanda views it as the most efficient way to control development and to tackle informal settlements (City of Kigali, 2013).

It is also argued that regulatory planning decisions are made with some appreciable level of certainty and absolute decision (Kayden, 2004). Thus, such systems ensure predictability on what could be permitted or not permitted on land - with developers, landowners and other actors in the built-environment being given more confidence, prior to planning permission. Additionally, the statutory nature of this system enables landowners or any third party to challenge decisions made against them in a court of law (Kayden, 2004). This is deemed to bring transparency in land market operations, and streamline planning decision-making.

\subsection{Issues in Regulatory Planning}

\subsubsection{Spatial Exclusion}

According to Devas (2001), planning regulation and building norms in most cities do not favor the poor, who constitute a substantial proportion of urban dwellers. Master planning and urban modernism models, completely fail to accommodate the way of life of the majority of inhabitants in rapidly growing, largely poor and informal cities (UN-Habitat, 2009). Some studies go on to suggest that, where a city authority strictly enforces zoning ordinances, it most likely causes more chaos (Malpezzi \& Mayo, 1997; Fox \& Goodfellow, 2016), with the likely result of periurban sprawl, as the urban poor fail to meet the cost of housing in the city (UN-Habitat, 2009).

With urban design being given greater emphasis, the adopted compliance standards under such planning systems favor housing typologies that only benefit affluent residents - leaving out the rest to the city's informal growth processes (Berrisford, 2014). This is also linked with the conflicting rationalities between the state and market, where by urban space is shaped by the workings of the market and the property industry (Malpezzi \& Mayo, 1997). Where there is state support of market-oriented planning, emphasis is placed on acquiring land in prime areas through the exercise of power of eminent domain, such as the eradication of informal settlements in favor of high-end housing that conforms to the design standards (Goodfellow, 2013). Over-regulation of the market shifts profitability towards high-end housing - discouraging investments in affordable housing.

\subsubsection{Increased Land and Housing Prices}

Urban development controls may restrict building height, floor area ratio, and the types of building materials that may be used for construction (Kayden, 2004). Nevertheless, Angel (2000), claims that in some developing countries that adopt these measures, governments rather 
become obsessed with urban modernism. This is further demonstrated by the manner with which planning policies in developing countries romanticize high-rise housing, vastly taken as the symbol of modernism (Buckley, 2014; Angel, 2000).

In practice, however, imposing zoning and growth controls could limit the capacity of urban residents with limited income, who heavily rely on locally available materials and incremental mechanisms to build their houses (Njoh, 1995). Also, since other growth factors such as migration can hardly be controlled by the same actions, such imbalances often result in acute housing deficits. Several studies have thus suggested a positive correlation between high housing prices and the imposition of urban development controls (Quigley,2007; Greene et al., 2016), as the latter makes the production of housing more expensive (Monkkonen,2013).

\subsection{A Case for Making Housing Affordable}

Given the primordial role that housing occupies in household consumption, welfare is assumed to be higher if all households can access decent and affordable housing (Whitehead, 2007). High housing costs can aggravate the vulnerability levels of low-income households and lead to housing-induced poverty. This may happen because while the average household would spend approximately a quarter of their income towards housing expenditures, a poor household would usually spend half of their income on housing as a result of the uneven distribution of household incomes (Quigley \& Raphael, 2004). Low-income households would not be able to afford other necessities after securing the quantity and quality of housing given the price and rent level that will be set by the demand from the majority of households in the society (Whitehead, 2007).

According to the UN-Habitat (2016), housing unaffordability varies in nature and magnitude depending on the region (see figure 1). Africa's housing price to income ratio of 12.5 is the highest among other regions, whereas its rent-to-income ratio of 39.5 comes in second, after the Arab States. These limitations are said to be the direct result of building standards and land use regulations that conform to the standards in developed countries and often used against the widely available and cost-effective building materials (UN-Habitat, 2011). While 85\% of Africa's urban populations cannot afford housing from the formal market, key elements such as land and finance are equally expensive for the majority of the continent's inhabitants (UNHabitat, 2011). 


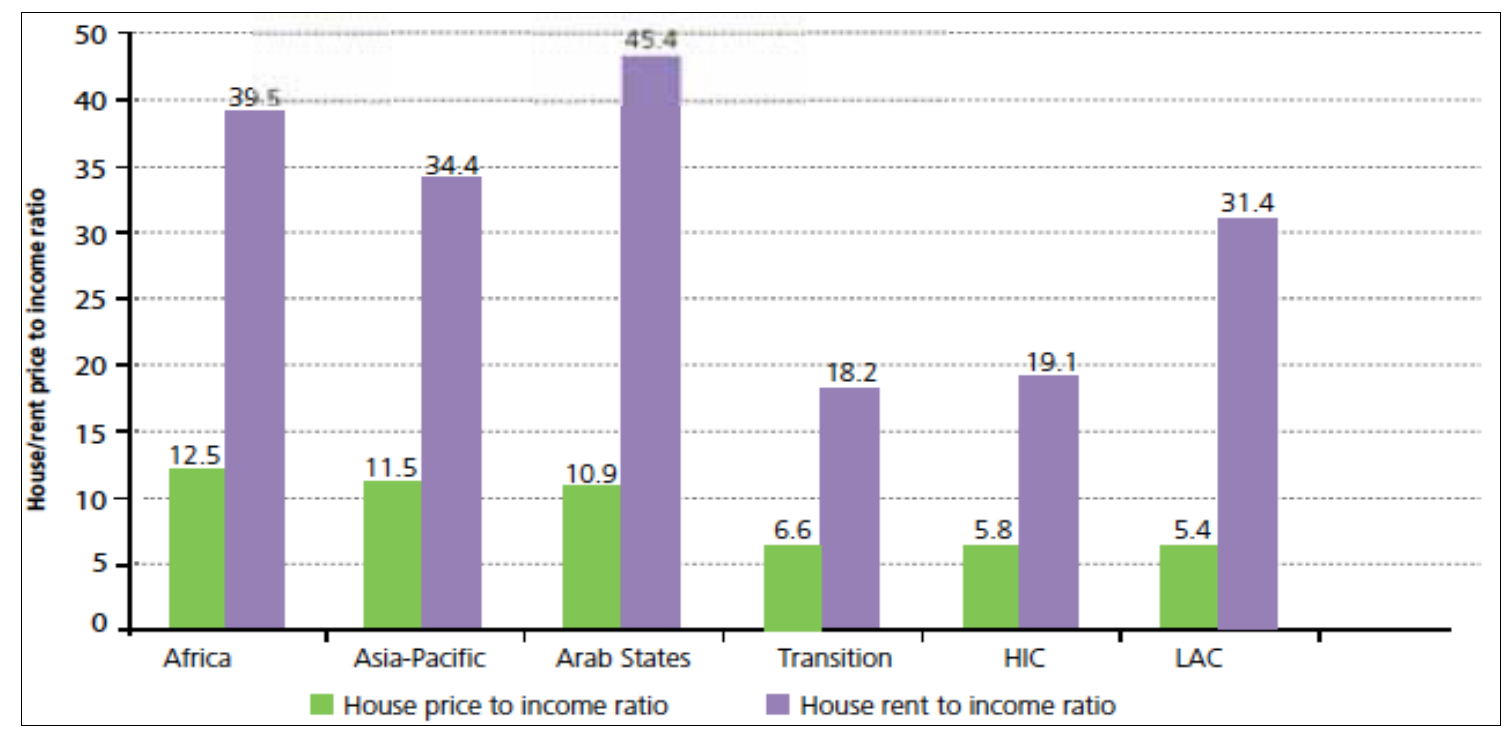

HIC: High Income Countries; LAC: Latin America and Caribbean.

Figure 1: Housing Price-Income Ratio and Rent-Income Ratio in Cities Source: Adapted from UN-Habitat (2011, p.25)

The above outlook shows that, access to affordable housing is a global challenge, and with many of the urban poor households being financially limited in terms of meeting the costs associated with quality housing as required by standards, an increase in the number of slum dwellers should be expected in the future (UN-Habitat, 2016). Consequently, the livelihoods of urban lowincome communities will continue to be threatened by limited possibilities to access decent and affordable housing in the formal market.

\section{Materials and Methods}

This study adopted the mixed research methods approach, since this method of enquiry helps to combine qualitative and quantitative approaches (Tashakkori \& Teddlie, 2008; Creswell \& Plano Clark, 2011); in this case the analysis of socio-economic dynamics of households, and spatial phenomena in the study area. Credence is given to the use of this method as it helps to neutralize biases inherent in individual methods (Creswell, 2003; Molina-Azorin, 2011), while allowing for easy triangulation and interpretation of different data sources (Morse \& Chung, 2003). The City of Kigali was chosen as the case study for this research because it has experienced noticeable changes in urban development and planning policies over the last two decades. Also, much of the different policy enforcements are given stricter considerations in Kigali, thus the city presented a more compelling case to investigate the relationship between master plan, zoning enforcements and the housing unaffordability problem.

According to Burgess et al. (1988 in Farthing, 2016, p.151) an extensive review of secondary data was conducted to understand how the shifts in policy and regulatory frameworks have affected the provision and access to affordable housing. Qualitative and quantitative data were gathered from scholarly sources such as textbooks, academic journals, working papers, 
organization reports, policy documents and laws. The key urban development policies that were reviewed include the Land Law, National Human Settlement Policy, and the National Urban Housing Policy. The following urban development laws were also examined; the Expropriation Law, the Land Use Planning Law, the Condominium Law, and the Land Law. Others included the existing urban development plans such as the Vision 2020, the EDPRS 1 \& 2, and the Kigali City Master Plan.

Studies by Bryman (2016), support the use of both methods in a single study as the qualitative data is often used to illustrate the quantitative findings. For this research, the qualitative data helped in understanding the perspectives of policies, laws and plans on access to housing, whilst the quantitative data offered an account on the extent to which housing affordability / unaffordability is experienced in Kigali, and how this relates to the current statutory policies and regulatory frameworks.

Discourse analysis was used together with cost analysis to synthesize the qualitative and quantitative datasets respectively. The use of discourse analysis helped in understanding the use of language, which are enshrined in the various documents and policy frameworks, within the context of Rwanda (Potter \& Wetherell, 1994; Farthing, 2016). Empirical researchers (Mayer \& Somerville, 2000; Glaeser \& Gyourko, 2003), have used cost analysis to explore changes in newbuild housing costs/prices over time. This study collected data on the material costs, labor and land costs to determine the total building cost for the cheapeststandard residential unit. Inferences were drawn from the changes in costsin the absence / presence of zoning ordinances and master plan enforcements. The resulting obtained data was subsequently compared to the median income within the case study area to detect the extent of any affordability gaps.

\section{Results and Discussions}

Much research in planning and urban geography, particularly in the global north have suggested that, excessive land use restrictions may drive up house prices and make it harder for urban communities with limited income to afford decent housing (Harney, 2009; Okpala 2009; Watson 2009a; Glaeser \& Gyourko, 2003; Monkkonen, 2013). This paper thus sought to explore the possible contributions that the enforcements of zoning regulations and other land use control measures in Kigali City could have had, on the reported shortages in affordable housing for low to medium income earners. The study progressed by looking at the socio-economic conditions of Kigali City's residents, the housing market situation in Kigali, government interventions in the housing market through the various policy and regulatory frameworks, and an analysis of the building costs in Kigali City.

\subsection{Socio-economic Situation in Kigali City}

\subsubsection{Household Incomes}

According to table 1, and figure 2, more than two-thirds of the total households in KigaliCity (78\%) earn an average monthly income that is below Rwf 300,000. Households that are considered to be affluent constitute about $1 \%$ of the city's population (earning incomes that are over Rwf 1,500,001). These results make it prudent for interventions in the provision of 
affordable housing, to emphasize on the vast majority of the Kigali City's resident (91\%) who earn less than Rwf 600,001. As suggested by Woetzel et al. (2014), cities with population of over 2 million have average-income households that are notable to afford housing in the formal market, hence a substantial number pursue informal and substandardhousing.

Table 1: Proportion of Income Quintiles

\begin{tabular}{llll}
\multirow{2}{\text{Quintil}}{} & \multicolumn{2}{l}{ Monthly Household Income $(\mathbf{R w f})$} & \multicolumn{2}{l}{$\begin{array}{l}\text { Proportio } \\
\mathbf{n}\end{array}$} \\
\cline { 2 - 4 } & From & To & $\mathbf{7 8}$ \\
\hline Q1 & $<$ & 300,000 & $\mathbf{1 4}$ \\
\hline Q2 & 300,001 & 600,000 & $\mathbf{5}$ \\
\hline Q3 & 600,001 & 900,000 & $\mathbf{2}$ \\
\hline Q4 & 900,001 & $1,500,000$ & $\mathbf{1}$ \\
\hline Q5 & $1,500,001$ & $<$ &
\end{tabular}

Source: Adapted from Planet Consortium (2012)

\subsubsection{Employment Rates and Categories}

Kigali City is the center for a majority of the urban activities in Rwanda, thus ittends toaccumulate the largest share of the country's employment. This is further characterized by the demographic structure of its population. About $73 \%$ of Kigali City's residents are under the age of 30 (REMA, 2013), and the city's labor force forms $79.3 \%$ of the population (NISR, 2016b).

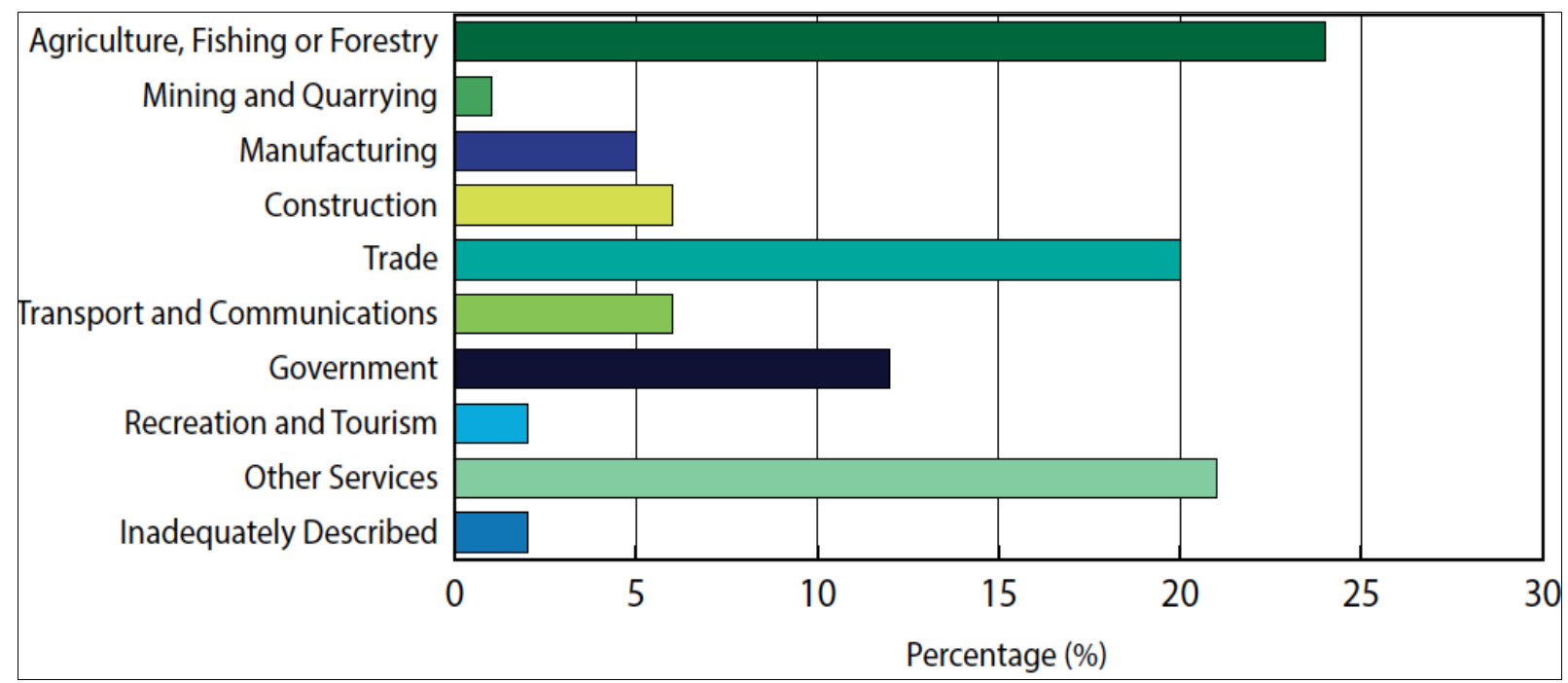

Figure 2: Proportion of Major Employment Sectors in Kigali City

Source: Adapted from REMA (2013, p.30) 
Despite having the highest concentration of economic activities in Rwanda, the levels of unemployment in Kigali have been noted to be on the rise. The rate of unemployment in Kigali (15.9\%) is about $5.7 \%$ higher than the national average (NISR, 2016a). Much of the country's unemployment is found among people between the ages of 16 and 30 (15.9\%), compared to the rates for people over 30 years (10.6\%). Indications from these results suggests that, more and more people will be moving from other locations in the Rwanda to Kigali City, primary for employment and also for the benefits of living in an urban area, in spite of the high rates of unemployment, particularly among the youth. This development will have further implications on the ongoing efforts to address the shortages in affordable housing in Kigali City - leading to more informal settlement developments in the city as the gap between demand and supply for housing continues to increase (UN-Habitat, 2013; UN-Habitat, 2016).

\subsubsection{Levels of Poverty and Inequality}

Tremendous progress has been made nationwide, to reduce poverty by $11.8 \%$ in the last few years (NISR, 2012a). Despite these developments, poverty continues to be prevalent and widespread in many areas of Rwanda. About $22 \%$ of Kigali City's population lives below the poverty line (World Bank, 2015). Additionally, inequality levels are generally high in Rwanda and these are mainly driven by location, education, and occupation (World Bank, 2015). While the Gini coefficient at the national level stands at 50.8, urban areas in Rwanda (including Kigali City) have a much higher Gini coefficient of 58 (World Bank, 2015). These results indicate that, there is a huge gap in people's ability to access basic consumption goods including housing, particularly for those who live in Kigali city. These results are supported by past studies (Quigley \& Raphael, 2004; Whitehead, 2007; Leishman \& Rowley, 2012), which suggest that whereas people at the top half of the income distribution may continue to enjoy an appreciable level of satisfaction after paying for housing and other consumption goods, low to medium income earners will be left with little or no satisfaction since a greater fraction of their earnings go into payments for housing.

\subsubsection{Extent of Access to Homeownership}

From the perspective of financial inclusion, about $21 \%$ of the people who own a bank account in Kigali City have a savings account (MININFRA, 2015). At the national level, only $4 \%$ of account holders borrow money from formal financial institutions to buy or build a house (Finscope, 2016). The above observation is somewhat intuitive in the sense that, borrowing to buy or build a formal residential unit, requires for an individual to earn a minimum monthly income of Rwf 990,000; corresponding to less than 3\% of the total households in Kigali City (Planet Consortium, 2012). Deposit requirements of up to $30 \%$ in some cases, makes mortgage finance inaccessible to people without formal employment. Additionally, high interest rates and difficult loan terms tends to exclude low and middle-income earners from formal housing finance (Nkurunziza et al., 2016). The cheapest subsidized unit of Rwf 6.3 million (table. 2) would be beyond the purchasing power of a household that earns less than Rwf 300,000 per month. 
Table 2: Purchase Affordability for Housing in Kigali City Average Household Income (Rwf)

Cost of Affordable Housing (Rwf)

$$
<300,000
$$

$6,300,000$

Required Household Income

Actual Cost of Formal Housing

$\begin{array}{rr}990,000 & \geq 20,000,000 \\ 4,935,000 & \geq 100,000,000\end{array}$

Source: Adapted from MININFRA (2015, p.8) Assumption: 18\% interest rate, and 15 years loan term.

\subsection{The HousingMarket in Kigali City}

\subsubsection{Tenure Structure and Composition}

The housing market in Kigali City is made up of rental housing, and owner-occupation housing (see figure 3). Renters form the largest proportion (53\%) of Kigali City's residents, and most of them consume informal housing (MININFRA, 2015). The high rate of renting households could be supported by the economic and socio-demographic factors which are assumed to influence decisions about whether to own or rent a house (Boehm 1993; Gabriel and Painter 2003; Haurin \& Rosenthal 2004; Di \& Liu 2007; Drew\& Herbert, 2013). In other words, consumption decisions are the product of preference for a particular good, the given constraints on the supply of that good, and the resources available to purchase it (Megbolugbe et. al., 1991).

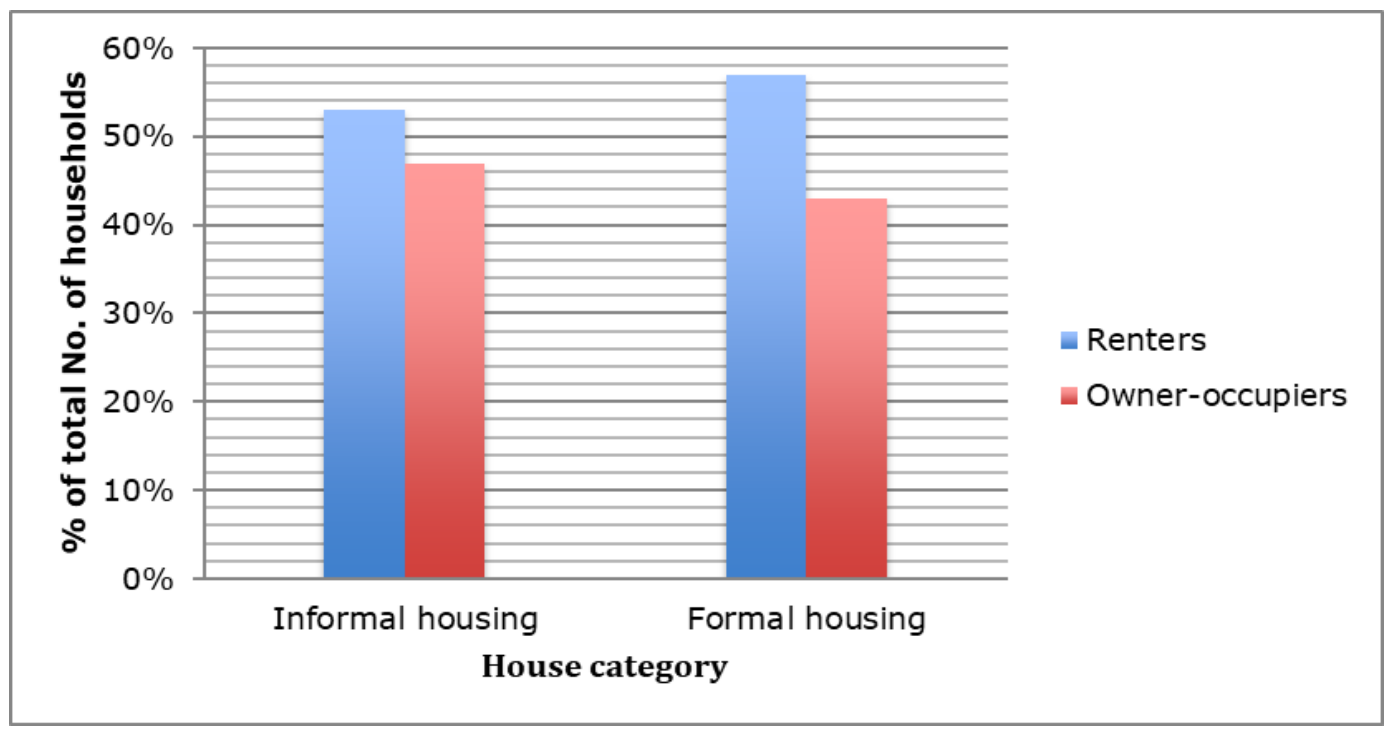

Figure 3: Housing Tenure Structure for the City of Kigali Source: Adapted from MININFRA (2015) 
Unlike the City of Kigali, tenure structure at the country level is predominantly owneroccupation. The latter accounts for $80 \%$ whereas renting households make up $15 \%$ of the total population (MININFRA, 2015). This could be due to the availability of cheap labor, land, and the lack of building restrictions in the outer regions of Rwanda, which makes housing costs largely affordable, as suggested by Megbolugbe et. al., (1991). With the majority of renting tenants (approximately 83\%) housed in areas located around the central business district of Kigali City, these same CBD locations are the most likely to undergo expropriation (Vegter, 2018) in the process of enforcing the master plan, making the housing situation of the affected residents dire, with the possibility for more slum developments in other areas of the city, if the expropriated households are not provided with affordable housing options.

\subsubsection{Housing Demand and Supply}

According to the Planet Consortium (2012), Kigali needs at least 31,000 housing units each year to satisfy its current housing demand. The same study goes on to say that only about 1,000 housing units could be supplied in the formal housing market, annually. Accordingly, table 3 and figure 4 indicate that, affordable housing constitutes the largest proportion of housing demand.

Table 3: Projected Housing Supply for Kigali City 2012-2020

$\begin{array}{lll}\text { New Dwellings (including } & \text { Dwelling Units } & \text { Percentage (\%) } \\ \text { backlog) to be built 2012-22 } & & \end{array}$

\begin{tabular}{lrr}
\hline Social Housing & 43.436 & 12.62 \\
\hline Affordable Housing & 186.163 & 54.11 \\
\hline Mid-range Housing & 112.867 & 32.80 \\
\hline Premium Housing & 1.601 & 0.47 \\
\hline & & \\
Total & $\mathbf{3 4 4 . 0 6 8}$ & $\mathbf{1 0 0}$ \\
\hline
\end{tabular}

Source: Adapted from Planet Consortium (2012) 


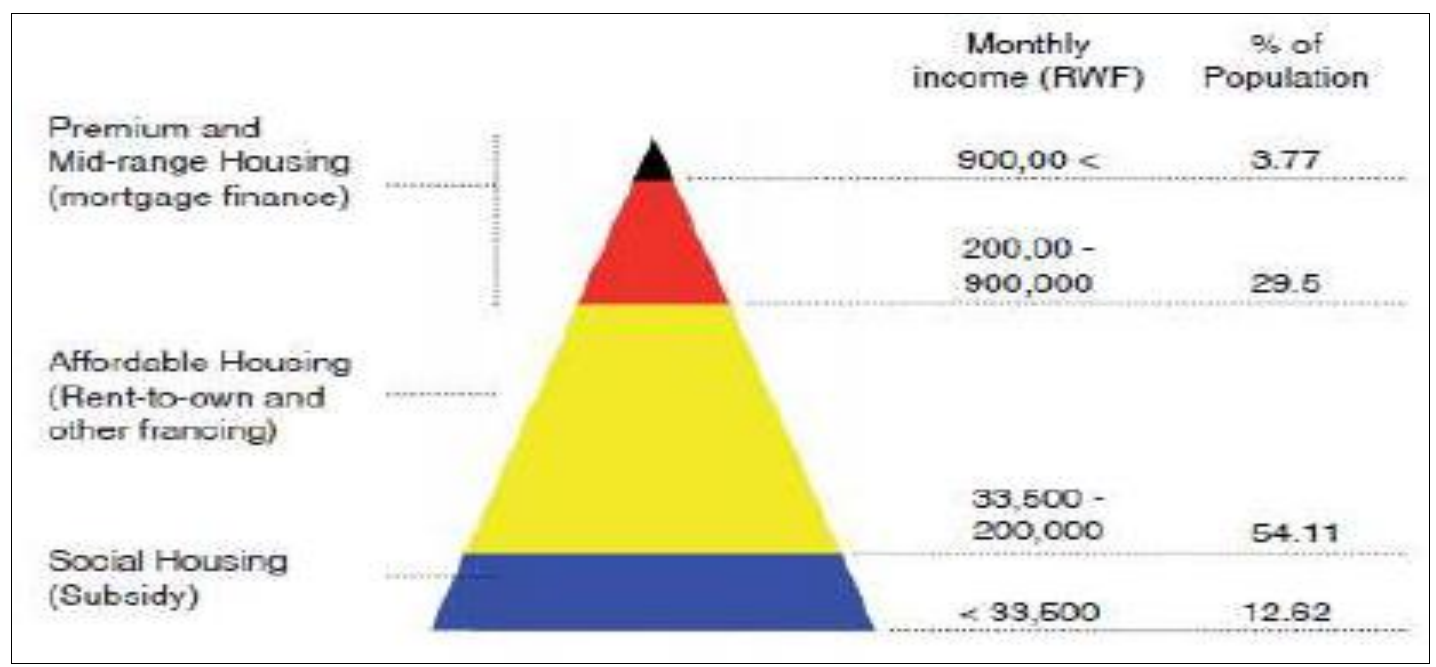

Figure 4: The Pyramid of Housing Supply in Kigali City Source: Adapted from Planet Consortium (2012)

The gaps in the supply of housing is echoed by the MININFRA (2015), that the housing subsector is challenged by the continuously growing demand for housing in urban and rural areas, coupled with the slow and expensive formal housing supply in urban areas, and the simultaneous sprawl of unsustainable house construction in rural areas. This is further demonstrated by the wide reportage of the housing unaffordability challenge among international and local media (Rosen, 2015; Anangwe, 2016). Others have gone on to emphasized that the provision of affordable and adequate housing in Rwanda is an urgent issue - to bridge the gap between housing demand and supply for low and middle-income earners (Byaruhanga, 2016). This will call for other mechanisms such as increased formal market supply, together with a combination of formal public-private partnerships, or the informal housing stock upgrading to supply the remaining 30,000 dwelling units. Studies suggest that, low-income households have some payment capacity (UN-Habitat, 2008) and could access a special rental market which may include, rent-to-own, rent control, direct subsidies, and tax subsidies (Chiquier\& Lea, 2009) for affordable housing projects.

\subsubsection{Government Interventions in Urban Development}

The post-genocide period in Rwanda has been marked by rapid urban urbanization particularly in Kigali City (MININFRA, 2015). In the presence of transitional institutions and poor infrastructure, much of the urban growth has taken place in spontaneous and uncontrolled manner (Manirakiza, 2012), giving way to the spread of informal settlements across Kigali City. However, existent studies argue in favor of government interventions in housing issues (Dowall, 1989; Angel, 2000; Buckley, 2014). Thus, the Government of Rwanda has instituted a number of policies, laws and strategic plans (see tables 4, 5, and 6) to redress the challenges posed by the rapid rate of urbanization, to ensure urban renaissance, and controlled spatial development. 
Table 4: Urban Development Policies in Kigali City

\begin{tabular}{|c|c|c|c|}
\hline Policies & Year & Objective & Affordable Housing Context \\
\hline Land Policy & 2004 & $\begin{array}{l}\text { It provides broad national } \\
\text { guidelines to land reforms } \\
\text { and land management } \\
\text { practices in Rwanda. }\end{array}$ & $\begin{array}{l}\text { "It acknowledges the need to } \\
\text { diversify availability of } \\
\text { developable plots to } \\
\text { accommodate anticipated urban } \\
\text { growth. Also, favourable } \\
\text { environment for access to } \\
\text { finance and affordable building } \\
\text { materials will be created and } \\
\text { supported" (p.39). }\end{array}$ \\
\hline $\begin{array}{l}\text { National Human } \\
\text { Settlement Policy }\end{array}$ & 2009 & $\begin{array}{l}\text { This policy seeks to improve } \\
\text { settlement conditions of the } \\
\text { urban population in } \\
\text { consistency with EDPRS I. }\end{array}$ & $\begin{array}{l}\text { "Rehabilitation of residential } \\
\text { areas gives priority to the } \\
\text { security of residents through } \\
\text { approaches such as rehousing" } \\
\text { (Strategy } 2.2, \text { p.19). }\end{array}$ \\
\hline $\begin{array}{l}\text { National Urban } \\
\text { Housing Policy }\end{array}$ & 2015 & $\begin{array}{l}\text { This policy seeks to ensure } \\
\text { adequate living conditions, } \\
\text { to enable all residents to } \\
\text { access housing, and to } \\
\text { establish and } \\
\text { anchor both objectives } \\
\text { within national policies and } \\
\text { programs. }\end{array}$ & $\begin{array}{l}\text { "For a housing development } \\
\text { scheme to be considered } \\
\text { affordable, it shall offer such } \\
\text { types of units, which are in } \\
\text { accordance with the real } \\
\text { income structure in the } \\
\text { concerned area. As an } \\
\text { indicative orientation, access to } \\
\text { housing is considered } \\
\text { affordable, if about a third of } \\
\text { the income is spent on it" } \\
\text { (Pillar1, p.16). }\end{array}$ \\
\hline
\end{tabular}

Source: Author's Construct, 2017

With reference to the existing urban development policies, the national urban housing policy in particular acknowledges access to housing as a basic right for every citizen (MININFRA, 2015). The policy also seems to emphasize on the governments' role of enabling the private sector to exhaust the current housing demand in terms of quantity and quality. Particularly, it advances a comprehensive multi-stakeholder approach to encourage more home building (MININFRA, 2015). In addition, the legal frameworks that surround land use management and planning supports individuals' rights to exploit and use land according to the existing plans, which is arguably done in the interests of meeting the master plan objectives.

However, in the past expropriation schemesin Kigali Cityhave rarely involved rehousing options as an alternative to a just compensation, which is normally provided to the affected households. Several studies (Cernea, 1999; Viitanen, 2002), have provided compelling evidence on the negative outcomes of a poor expropriation exercise which may come about as a result of the 
uncertain and hypothetical nature of market prices - the property market does not always exist in a form which allows for ready replacement of land and livelihoods. The situation with rising land and house prices in Kigali City (Selina et al., 2015) may seem to suggest that, the housing conditions ofexpropriated populations in most cases generally get worse, than they were before.

Additionally, the definitions provided by the National Urban Housing Policy for "affordability" is inadequate as it does not make any provision for the quality of housing for different income groups, instead it seems to consider the affordability impartially to all people. The lack of clarity in defining affordability may also be the result of the hugely divergent and subjective meanings that are often attributed to the concept (Hulchanski, 1995; Stone, 2006; UN-Habitat, 2011; Smets et al., 2014). This may also confirm the suggestions of Leishman \& Rowley (2012), that, when the indicators used to describe housingaffordability are misguided they do not respond adequately to the true incidence of the housing unaffordability problems.

The Land Policy on its own does provide mechanisms to unlock the supply of land for housing. However, Article 8 sites with a total land area of about 55 hectares in the City of Kigali and the 6 Secondary Cities, have been opened for investors through the Districts to develop high density, mixed use housing to help in increasing supply in the short term (CAHF, 2018). Again, the affordability issue has not been succinctly addressed in these new provisions for the supply of housing, and the escalation of housing costs are expected to continue, as land constitutes an integral part of housing construction (World Bank, 2012) any responsive changes in demand, can lead to high house prices (Malpezzi \& Mayo, 1997).

Table 5: Urban Development Laws in Kigali City

\begin{tabular}{|c|c|c|c|}
\hline Laws & Year & Objective & Affordable Housing Context \\
\hline $\begin{array}{l}\text { Expropriation } \\
\text { Law }\end{array}$ & 2009 & $\begin{array}{l}\text { It determines procedures } \\
\text { relating to expropriation } \\
\text { in the public interest. }\end{array}$ & $\begin{array}{l}\text { "Activities of public interests include } \\
\text { those undertaken to implement land } \\
\text { use and development master plans" } \\
\text { (Article 5). }\end{array}$ \\
\hline $\begin{array}{l}\text { Land Use } \\
\text { Planning Law }\end{array}$ & 2012 & $\begin{array}{l}\text { It makes provisions the } \\
\text { planning of land use and } \\
\text { development in } \\
\text { Rwanda. }\end{array}$ & $\begin{array}{l}\text { "The land use mode may only be } \\
\text { changed with the approval of the } \\
\text { competent authority and it is done } \\
\text { through a written application" } \\
\text { (Article } 10 \& 11) \text {. }\end{array}$ \\
\hline $\begin{array}{l}\text { Condominium } \\
\text { Law }\end{array}$ & 2010 & $\begin{array}{l}\text { Creates and organises } \\
\text { condominiums and sets } \\
\text { up procedures for their } \\
\text { registration }\end{array}$ & $\begin{array}{l}\text { "A type of joint ownership of real } \\
\text { estate in which portions of the } \\
\text { property are commonly owned and } \\
\text { other portions are individually } \\
\text { owned" (Article 2). }\end{array}$ \\
\hline Land Law & 2013 & $\begin{array}{l}\text { It determines modalities } \\
\text { of allocating, acquiring, } \\
\text { transferring, using and } \\
\text { managing land in }\end{array}$ & $\begin{array}{l}\text { "Land is considered not properly } \\
\text { exploited when it is meant for } \\
\text { buildings and/or infrastructures is not } \\
\text { developed within the period } \\
\text { prescribed by competent authority" }\end{array}$ \\
\hline
\end{tabular}




\begin{tabular}{|l|l|l|l|}
\hline & & Rwanda. & $($ Article 41). \\
& & & \\
\hline
\end{tabular}

Source: Author's Construct, 2017

Among the four key laws for urban development in Kigali City, the Condominium Law tends to supports the efforts of individuals to collectively buy/build and own housing units within a single building. This may be regarded as one of the very ingenious ways of providing affordable housing to low-incomes earners but care should be taken in the allocation of rights to individuals, in the event that a party decides to opt out of the scheme. With regards to the Expropriation Law, it does not provide accurate information and guidelines on how expropriated households would be facilitated to access housing at new locations. Also, the provisions in Article 5 of the same law are stated broadly to involve private interests that do not necessarily benefit the wider community. The outcomes of poorly executed expropriations have been noted to ultimately worsen the housing situation of affected residents (Cernea, 1999; Viitanen, 2002). Additionally, the confiscation of undeveloped lands after a period of 3-years as enshrined in the Land Law could pose a challenge, for poor households who might not have the financial capacity to meet the costs associated with the prescribed housing design standards.

Furthermore, the Government of Rwanda has passed two legal instruments to attract private developers' interests in affordable housing. First among these is the Prime Minister's instructions No. 004/03 of 13/09/2015, which is aimed at determining the conditions and procedures for obtaining government support for affordable housing projects through the provision of basic infrastructure (Republic of Rwanda, 2015b). Additionally, there is a proposed Urban Development Fund, which will financially facilitate public infrastructure delivery and project screening and approvals (MININFRA, 2015). The second legal tool is the Law $\mathrm{N}^{\circ} 06 / 2015$ of 28/03/2015, relating to investment promotion and facilitation (Republic of Rwanda, 2015b). This instrument is part of a broad range of government strategies to incentivize private investments into affordable housing. It also sets out the conditions for a wide range of incentives provided to developers of affordable housing including tax relaxation, which are major contributors to making housing affordable (Njiru \& Moronge, 2013).

In response to the issues of urbanization, the City of Kigali embarked on a planning regime supported by master plan and zoning regulations (OZ Architecture, 2007; Sharma, 2012). Developed in 2007 and approved by the Parliament in 2008, the city's master plan (see table 6), which has been under revision since 2018, supports the segregation of land uses through zoning regulations. The latter are legally binding under the law relating to the planning of land use and development (Manirakiza, 2012).

Table 6: Urban Development Plans in Kigali City

\begin{tabular}{|l|l|l|l|}
\hline Plans & Year & Objective & Affordable Housing Context \\
\hline
\end{tabular}




\begin{tabular}{|c|c|c|c|}
\hline Vision 2020 & 2002 & $\begin{array}{l}\text { It is a long-term multi- } \\
\text { sectorial strategic plan with a } \\
\text { number of objectives relevant } \\
\text { to urbanization and human } \\
\text { settlement. }\end{array}$ & $\begin{array}{l}\text { "It sets out strategies to avoid } \\
\text { uncontrolled growth by a } \\
\text { coordinated planning, and to } \\
\text { provide access to basic } \\
\text { infrastructure services, such as } \\
\text { shelter, electricity and } \\
\text { drainage. It relates } \\
\text { urbanization to economic } \\
\text { growth." }\end{array}$ \\
\hline EDPRS I \& II & 2008 & $\begin{array}{l}\text { It is a mid-term sectorial } \\
\text { strategic plan. Phase I was } \\
\text { valid between 2008-12 and } \\
\text { phase II between 2013-2017. }\end{array}$ & $\begin{array}{l}\text { "The local governments are } \\
\text { responsible for the } \\
\text { management of development } \\
\text { and urban growth, but are still } \\
\text { weak and insufficiently staffed } \\
{[\ldots] \text {... }}\end{array}$ \\
\hline $\begin{array}{l}\text { Kigali City Master } \\
\text { Plan }\end{array}$ & 2013 & $\begin{array}{l}\text { It is based on initial } \\
\text { conceptual master plan } \\
\text { developed in 2007, and forms } \\
\text { a broad roadmap for spatial } \\
\text { development of the city and } \\
\text { features individual physical } \\
\text { plans for each district. }\end{array}$ & $\begin{array}{l}\text { It contains detailed land use } \\
\text { and zoning plans that will } \\
\text { guide the city's anticipated } \\
\text { urban design. The housing } \\
\text { context of the plan is analysed } \\
\text { in details under theme } 3 .\end{array}$ \\
\hline
\end{tabular}

Source: Author's Construct, 2017

This master plan embodies a comprehensive guide of anticipated growth and development and forms the roadmap to the city's long-term aspiration to be the 'center for urban excellence' (City of Kigali, 2013). More specifically, the master plan envisages the look of Kigali City's urban fabric in the next 50 to 100 years - embodied in detailed development frameworks for each of the city's three districts. These are accompanied by zoning plans and regulations which "regulate the types of uses, development intensity, the setting and height of buildings on any plot" (Joshi, 2013 , p.2). The ongoing efforts of the Government of Rwanda and other planned interventions to support affordable housing delivery reveals the magnitude of the issue, and how it is treated diligently.

\subsection{Building Standards and Housing Costs / Prices}

The master plans' clarification on the nature of development permitted and not permitted on individual plots, would ultimately have implication on the delivery cost of different housing typologies in Kigali city as it was evidenced elsewhere (Berrisford, 2014; Habitat, 2016; Buckley, 2014; Greene et al., 2016), and some of these costs are sometimes misguided. There are instances where mid-range housing proposals are categorized as 'affordable' in local marketing portals - as in the case of a recent condominium apartment. Within this apartment the cheapest housing unit was priced at Rwf 28 million (Agutamba, 2015), which is far higher than the upper limit cost / price (Rwf 6.3 million) for an affordable housing unit, as recommended by the 
National Housing Policy (MININFRA, 2015). In order to trace the cost implication of building and zoning standards on housing development, the cost analysis of building materials for an informal housing typology, is contrasted with that of a typical formal housing unit, which is required by the zoning code for the least restrictive neighborhoods.

\subsubsection{Cost Analysis of Informal Housing Typologies}

The majority of informal houses in Kigali are built using personal sources of finance, incrementally, depending on the owner's capacity. The construction is largely dependent on the readily available local building materials which also commands cheaper costs. Tables 7 and 8 provide the cost details for using locally sourced material in housing construction, in Kigali. The labor required to build this kind of housing is available locally and comes in at a cheap cost.

Table 7: Material Cost for an Informal Housing Typology

\begin{tabular}{llrl} 
Material & Cost $($ Rwf $)$ & Unit \\
\hline 1 Mud brick & $\mathbf{6 8 6}$ & $\mathrm{m}^{2}$ \\
2 Cement screed flooring & $\mathbf{4 , 5 0 4}$ & $\mathrm{m}^{2}$ \\
3 Rammed earth walls, with timber struts & $\mathbf{5 4 0}$ & $\mathrm{m}^{2}$ \\
4 Clay roofing tile & $\mathbf{9 , 9 9 6}$ & $\mathrm{m}^{2}$ \\
5 & Volcanic stone & $\mathbf{3 6 , 0 0 0}$ & $\mathrm{m}^{3}$ \\
6 Timber including bamboo & $\mathbf{2 , 0 0 0}$ & piece $(\approx 3 \mathrm{~m}$ long $)$ \\
7 & Mud plaster & $\mathbf{3 0 0}$ & $\mathrm{m}^{3}$ \\
\hline
\end{tabular}

Source: Adapted from World Bank (2012)

Table 8: Estimated Land Acquisition and Construction Costs for the Cheapest Informal House in a Sub-urban Area (R2A)

\begin{tabular}{lllrrr}
\hline No. & Description & Unit & Qty & Cost/unit & Total \\
\hline I. & Site acquisition and building permit costs & & & & \\
\hline $\mathbf{1}$ & Estimated land price & $\mathrm{m}^{2}$ & 90 & 30,000 & $2,700,000$ \\
\hline $\mathbf{2}$ & Title transfer costs & Rwf & & 45,000 & 45,000 \\
\hline & TOTAL & & & & $\mathbf{2 , 7 4 5 , 0 0 0}$ \\
\hline & & & & & \\
\hline II. & House building costs & Rwf & 1 & 69,000 & 69,000 \\
\hline $\mathbf{1}$ & Estimated construction cost/sqm & $\mathrm{m}^{2}$ & 1 & 76 & 76 \\
\hline $\mathbf{2}$ & Estimated built-up area for 3-bedroom unit & & & & $\mathbf{5 , 2 4 4 , 0 0 0}$ \\
\hline & TOTAL & & & & \\
\hline & SUB TOTAL & & & $\mathbf{7 , 9 8 9 , 0 0 0}$ \\
\hline
\end{tabular}

Source: Adapted from World Bank (2012) 
The estimated minimum building cost including land for a single-family unit (3-bedrooms) is approximately Rwf 8 million using quotations from the above tables. Practically, this housing typology would be affordable to many of thecity's households, since this rate is not too high when compared to the Rwf 6.3 million set by the MININFRA (2015). Given a flexible loan term, and a proportionate rate of interest, such housing typologies can go farther to meet the housing needs of a greater majority of Kigali City's residents, including those earning less than Rwf 300,000 per month. But there are prevalent disinclinations against these types of housing among policy-makers on the grounds that they are non-modern and regressive (World Bank, 2012). Thus, those types of housing are not permitted under the current land zoning codes (Joshi, 2013), making the plight of many low to medium incomes earners more pronounced in their efforts towards affordable housing (Nduka \& Kalu, 1986; Nubi 2008; Kagire, 2014).

\subsubsection{Cost Analysis of Formal House Typologies}

The master plan and zoning require new forms of urban design atthe city level. In addition, zoning regulations imply the use ofdurable materials as per the building codes. These requirements are also necessary because, high-rise construction is highly encouraged by the currentmaster plan (Sharma, 2012).

Tables 9 and 10, presents the cost analysis of materials fora formal housing unit as per the zoning codes, in Kigali City. There is insufficient local manufacturing capacity - much of the building materials are imported, and this makes them cost higher by the time they arrive in the country (Mathema, 2012). Furthermore, the use of these materials can sometimes require the hiring of foreign skilled labor (Mathema, 2012). Thus, the cheapest formal housing unit (3-bedrooms) including land would cost approximately Rwf 16 million which is relatively expensive for the ordinary residents of Kigali City.

Table 9: Material Cost for a Formal House Typology

\begin{tabular}{rlrl} 
& Material & Cost $($ Rwf $)$ & Unit \\
\hline 1 & Reinforced cement concrete & $\mathbf{3 5 0 , 0 0 0}$ & $\mathrm{m}^{3}$ \\
2 & Plain cement concrete brick & $\mathbf{2 6 , 1 7 9}$ & $\mathrm{m}^{2}$ \\
3 & Hollow concrete block & $\mathbf{1 7 , 0 7 9}$ & $\mathrm{m}^{2}$ \\
4 & Fired brick & $\mathbf{1 0 , 4 5 2}$ & $\mathrm{m}^{2}$ \\
5 & Steel & $\mathbf{2 3 0}$ to $\mathbf{1 5 5 0}$ & piece (diameter $\leq 12 \mathrm{~m}$ length \\
6 & Glass & $\mathbf{7 , 0 0 0}$ to $\mathbf{1 8 , 0 0 0}$ & $\mathrm{m}^{2}$ (thickness $\left.\leq 8 \mathrm{~mm}\right)$ \\
7 & Aluminum doors and windows & $\mathbf{1 5 5 , 0 3 7}$ & $\mathrm{m}^{2}$ \\
8 & Granite tile & $\mathbf{1 6 , 0 0 0}$ & $\mathrm{m}^{2}$ \\
9 & Ceramic tile & $\mathbf{8 , 5 0 0}$ & $\mathrm{m}^{2}$ \\
10 & Marble & $\mathbf{3 0 , 0 0 0}$ & $\mathrm{m}^{2}$ \\
11 & Vitrified tiles & $\mathbf{6 , 7 0 0}$ & $\mathrm{m}^{2}$ \\
\hline
\end{tabular}

Source: Adapted from World Bank (2012) 
Table 10: Estimated Land Acquisition and Construction costs for the Cheapest Formal House Unit in a Sub-urban Area (R2A)

\begin{tabular}{lllrrr}
\hline No. & Description & Unit & Qty & Cost/unit & Total \\
\hline I. & Site acquisition and building permit costs & & & & \\
\hline $\mathbf{1}$ & Estimated land price & $\mathrm{m}^{2}$ & 90 & 30,000 & $2,700,000$ \\
\hline $\mathbf{2}$ & Title transfer costs & Rwf & 45,000 & 45,000 \\
\hline $\mathbf{3}$ & Building permit costs & Rwf & 186,000 & 186,000 \\
\hline & TOTAL & & & & $\mathbf{2 , 9 3 1 , 0 0 0}$ \\
\hline & $\quad$ & & & \\
\hline II. & House building costs & Rwf & 1 & 185,000 & 181,000 \\
\hline $\mathbf{1}$ & Estimated construction cost/sqm & $\mathrm{m}^{2}$ & 1 & 70 & 70 \\
\hline $\mathbf{2}$ & Estimated built-up area for 3-bedroom unit & & & & $\mathbf{1 2 , 6 7 0 , 0 0 0}$ \\
\hline & TOTAL & & & & $\mathbf{1 5 , 6 0 1 , 0 0 0}$ \\
\hline & SUB TOTAL
\end{tabular}

Source: Adapted from World Bank (2012)

A practical example of the outcomes of the above analysis for formal housing can be extracted from the zoning requirements for Batsinda neighborhood in Gasabo District, which is one the immediate administrative unit of Kigali City Province (see table 11). In this residentially zoned area, the permitted land uses are affordable low-rise residential housing, and apartments. However, the required building coverage of $60 \%$ for landed housing and attached houses (Joshi, 2013), discourages horizontal construction, infavor of vertical construction. The direct consequence of building vertically would require for the use of imported and expensive materials (described in table 11). Compared to other residential zones, these regulations for the Batsinda neighborhoods have been designed to support the development of suburban affordable housing (R2A). Yet the largest portion of low-income households lives in central areas (REMA, 2013; Nduwayezu, 2015). This in itself puts another dilemma on the housing upgrading and resettlement programs. 
Table 11: Excerpts of Zoning Regulations for Batsinda Neighborhood

\begin{tabular}{|c|c|}
\hline Specification & Regulation \\
\hline Zone & The low-rise residential district (R2A) \\
\hline General description & $\begin{array}{l}\text { The purpose of R2A District is to create an affordable low-rise housing } \\
\text { district by allowing higher building coverage and higher intensity low-rise } \\
\text { development in suburban new towns. }\end{array}$ \\
\hline Permitted uses & $\begin{array}{l}\text { - Low rise apartments } \\
\text { - Townhouses }\end{array}$ \\
\hline Minimum lot size & $\begin{array}{l}\text { Type 1: } \bullet \text { Lot size of } 90 \mathrm{~m} 2 \text { for landed housing development, semi-detached } \\
\& \text { attached houses }\end{array}$ \\
\hline & $\begin{array}{l}\text { Type } 2: \bullet \text { Minimum lot size of } 600 \mathrm{~m} 2 \text { for multi-family apartments. All } \\
\text { developments need to provide minimum of } 90 \text { Dwelling Units }\end{array}$ \\
\hline Building coverage & $\begin{array}{l}\text { - } 40 \% \text { for apartment } \\
\text { - } 60 \% \text { for landed house, attached houses }\end{array}$ \\
\hline $\begin{array}{l}\text { Maximum Floor } \\
\text { Area Ration (FAR) }\end{array}$ & $\cdot 1.4$ maximum \\
\hline Existing buildings & $\begin{array}{l}\text { Additions and alterations necessary to retain an existing approved legally non- } \\
\text { conforming building and its use in good order and repair will be allowed, } \\
\text { subject to: }\end{array}$ \\
\hline & $\begin{array}{l}\text { - No material changes in use which does not comply with the prevailing } \\
\text { zoning regulations; } \\
\text { - No further increase in floor area of the existing non- conforming use } \\
\text { - Any additional floor area required for the non-conforming use will: } \\
\text { - Be subject to the evaluation and approval of the City of Kigali, One Stop } \\
\text { Centre; and } \\
\text { - Not to exceed } 10 \% \text { of the existing use }\end{array}$ \\
\hline
\end{tabular}

\section{Source: Adapted from Joshi (2013, p.30)}

Manirakiza (2014), suggests for zoning tools to be flexible - guiding instruments that are aimed at sustainable inclusive urban development. In other words, flexibility in master plan implementation is necessary to regulate these high-rise buildings supply proportional to their demand, and also explore other instruments that may help to make financing available to boost the supply of housing. 


\section{Conclusions and Recommendations}

This paper explored the links between zoning-based planning systems and the declining rate of affordable housing, for low to medium income earners in the City of Kigali. Previous studies in locations such as the USA, Brazil, Malaysia and Cameroun suggested astrong correlation between zoning strictness and rise in housing costsand prices.

The findings of the current study found that, the City of Kigali is committed to addressing the effects of uncoordinated urbanization, which reigned its landscapes for many decades. This is reflected in the existing policy and regulatory frameworks, which encourage city authorities to segregate incompatible land uses and undertake large-scale gentrification projects to meet the masterplan's outlook. However, there are discrepancies between its assumptions and the existing socio-economic conditions, which tends to impose huge costs on housing. The provisions of the current master plan and zoning codes do not respond adequately to the immediate housing needs of low-income communities - instead, they seem to further undermine their traditional means of access to affordable housing. While the majority of residents of Kigali City are constrained by income, only a small proportion can effectively access mortgage loans from the financial institutions.

This study also noticed that, the housing typologies that are permitted under the zoning regulations largely require for the use of imported materials, labor and technology which are not locally available. Thus, the poor can hardly afford the resultant housing costs without subsidies, while high-end housing development flourishes only to benefit less than 5\% of the city's population. Thus, together with the government's efforts as an enabler of affordable housing, this study suggests for a more direct involvement in housing development. Additionally, there is the need to develop alternative housing finance mechanisms to facilitate those in lower-income distributions, to access funds under more flexible loan terms.

This study proposes further explorations which will apply cutting edge econometrics procedures to capture more precise changes in housing costs and prices, as a result of the restrictions of the master plan and zoning ordinances which are currently in force in Kigali City. Also, further research is needed to establish a database for housing affordability and to adapt this concept to the context of Kigali City. This could serve as a basis to identify beneficiaries of future affordable housing projects, and to monitor affordability indices as an important indicator for quality of life within Kigali City. 


\section{References}

Agutamba, K., 2015. Homeowners Worried as Housing Deal Teeters. The New Times. p.1. Available at: http://www.newtimes.co.rw/section/article/2015-01-21/185158/ (Accessed June 23, 2018).

Anangwe, E., 2016. The Debate on Availability and Affordability of Housing in Rwanda.

Angel, S., 2000. Housing Policy Matters: A Global Analysis. New York: Oxford University Press.

Beall, J. \& Fox, S., 2009. Cities and Development. London: Routledge.

Berrisford, S., 2014. The Challenge of Urban Planning Law Reform in African Cities. In S. Parnell \& E. Pieterse, eds. Africa's Urban Revolution. New York, pp. 167-183.

Biderman, C., 2008. Informality in Brazil: Does Urban Land Use and Building Regulation Matter?

Boehm, T. P., 1993. Income, Wealth Accumulation, and First Time Homeownership: An Intertemporal Analysis. Journal of Housing Economics 3, no. 1: 217-32.

Booth, P., 1995. Zoning or Discretionary Action: Certainty and Responsiveness in Implementing Planning Policy. Journal of Planning Education and Research, 14(2), pp.103-112.

Bryman, A., 2016. Social Research Methods 5th ed., Oxford: Oxford University Press.

Buckley, R., 2014. Affordable Housing in Rwanda: Opportunities, Options and Challenges: Some Perspectives from the International Experience. In Rwanda National Forum on Sustainable Urbanization. Kigali: The Centre for International Growth.

Byaruhanga, F., 2016. How Rwanda can Solve Affordable Housing Challenge. The New Times, p.1. Available at: http://www.newtimes.co.rw/section/article/2016-05-31/200338/ (Accessed June 15, 2016).

Center for Affordable Housing Finance in Africa, 2018. Housing Finance in Africa: A Review of Africa's Housing Finance Markets. Johannesburg, South Africa.

Cernea, M. M., 1999. The Economics of Involuntary Resettlement: Questions and Challenges. The International Bank for Reconstruction and Development / The World Bank, Washington D. C.

Chiquier, L., \& Lea, M., 2009. Housing Finance Policy in Emerging Market. Washington: The World Bank, London.

City of Kigali, 2013. Kigali City Master Plan Report. Available at: http://www.kigalicity.gov.rw/fileadmin/Template/Documents/reports/KIF_29.01. 2014_Master_Plan_Presentation.pdf (Accessed June 17, 2016).

Creswell J. W., \& Plano Clark, V. L. (2011). Designing and Conducting Mixed Methods Research. (2nd Ed.). Thousand Oaks, CA: Sage.

Creswell, J. W., 2003. Research Design: Qualitative, Quantitative Methods and Mixed Methods Approaches. (2nd ed.), London: Sage.

Creswell, J. W., 2009. Research Design: Qualitative, Quantitative and Mixed Approaches. (3rd Edition), London: Sage.

Devas, N., 2001. Does City Governance Matter for the Urban Poor? International Planning Studies, 6(4), pp.393-408.

Di, Z. X., \& Liu, X., 2007. The Importance of Wealth and Income in the Transition to Homeownership. Cityscape 9, No. 2: 137-52. 
Dowall, D. E. \& Clarke, G., 1996. A Framework for Reforming Urban Land Policies in Developing Countries. Washington, DC.

Dowall, D. E., 1989. Bangkok: A Profile of an Efficiently Performing Housing Market. Urban Studies, 26, 327-339.

Drew, R. B., \& Herbert, C., 2013. Post-Recession Drivers of Preferences for Homeownership. Housing Policy Debate 23, no. 4: 666-87.

Farthing, S., 2016. Research Design in Urban Planning: A Student's Guide. London: Sage.

Finscope, 2015. Financial Inclusion in Rwanda 2015. Available at: https://finmark.org.za/financial-inclusion-in-rwanda-2016/ (Accessed June 10, 2016).

Fischel, W. A., 1995. Regulatory Takings: Law, Economics and Politics. Cambridge: Harvard University Press.

Fischel, W., 1999. Zoning and Land Use Regulation. Encyclopedia of Law and Economics. pp.403-442.

Fox, S. \& Goodfellow, T., 2016. Cities and Development. (2nd ed.), New York: Routledge.

Gabriel, S., \& Painter, G., 2003. Pathways to Homeownership: An Analysis of the Residential Location and Homeownership Choices of Black Households in Los Angeles. Journal of Real Estate Finance and Economics 27, no. 1: 87-109.

Gan, Q. \& Hill, R. J., 2009. Measuring Housing Affordability: Looking Beyond the Median. Journal of Housing Economics.

Glaeser, E. L. \& Gyourko, J., 2002. The Impact of Zoning on Housing Affordability. Cambridge.

Glaeser, E. L. \& Gyourko, J., 2003. The Impact of Building Restrictions on Housing Affordability. FRBNY Policy Review, (June), pp.21-39.

Goldblum, C., 2008. Planning the World Metropolis on an Island-City Scale: Urban Innovation as a Constraint and Tool for Global Change. In W. Tai-Chee, B. Yuen, \& C. Goldblum, eds. Spatial Planning for Sustainable Singapore. Singapore: Springer.

Gonzalez, S., 2011. Bilbao and Barcelona 'in Motion'. How Urban Regeneration 'Models' Travel and Mutate in the Global Flows of Policy Tourism. Urban Studies, 48(7), pp.1397-1418.

Goodfellow, T., 2013. Planning and Development Regulation Amid Rapid Urban Growth: Explaining Divergent Trajectories in Africa. Geoforum, 48, pp.83-93.

Greene, J. C., Caracelli, V. J. \& Graham, W. F., 2016. Toward a Conceptual Framework for Mixed-Method Evaluation Designs. 11(3), pp.255-274.

Harney, B., 2009. Economics of Exclusionary Zoning and Affordable Housing. Stetson Law Review, 38(91), p.459.

Haurin, D. R. \& Rosenthal, S. S., 2004. The Sustainability of Homeownership: Factors Affecting the Duration of Homeownership and Rental Spells. Washington: U.S. Department of Housing and Urban Development, Office of Policy Development and Research.

Healey, P. \& Upton, R. (Eds), 2010. Crossing Borders: International Exchange and Planning Practices. RTPI Library Series. London and New York, NY: Routledge.

Healey, P. \& Williams, R., 1993. European Urban Planning Systems: Diversity and Convergence. Urban Stud Urban Studies, 30(45), pp.701-720.

Healey, P., 2013. Circuits of knowledge and techniques: The Transnational Flow of Planning Ideas and Practices. International Journal of Urban and Regional Research, 37(5), pp.1510-1526. 
Hui, E. C. M. \& Ho, V. S. M., 2003. Does the Planning System Affect Housing Prices? Theory and Evidence from Hong Kong. Habitat International, 27(3), pp.339-359.

Hulchanski, J. D., 1995. The Concept of Housing Affordability: Six Contemporary Uses of the Housing Expenditure-to-income Ratio. Housing Studies, 10(4).

Ikeda, S. \& Washington, E., 2015. How Land-Use Regulation Undermines Affordable Housing. Arlington: Mercatus Center-George Mason University.

Joshi, S., 2013. Gasabo District Zoning Plan. p.159.

Kagire, M., \& Mfitimana, V., 2014. High Rent Drives Traders out of Kigali Malls, Markets. The East Africa, p.1. Available at: http://www.theeastafrican.co.ke/rwanda/News/High-rent-drives-traders-out-ofKigali-malls-and-markets/1433218-2450460-wy3k6w/index.html(Accessed on July 4, 2017).

Kayden, J. S., 2004. Reconsidering Zoning: Expanding an American Land-Use Frontier. American Planning Association, 1(4), pp.1-15.

Khan, S., Kanyiginya, V., Kiema, J., Lengoiboni, M. N., Tumusherure, W., Ngabo, V., Hassan, R. M., \& Damascene, S. J., 2015. Influence of Urban Land Policies on Land Markets and People's Livelihoods in Urban Rwanda. In 2015 World Bank Conference on Land and Poverty. DC: World Bank.

Kolesnikov-Jessop, S., 2010. Singapore Exports its Government Expertise in Urban Planning. The New York Times, p.1. Available at: http://www.nytimes.com/2010/04/28/business/global/28urban.html?_r=0 (Accessed June 15, 2016).

Lai, L. \& Chung, W., 1994. The Economics of Land-Use Zoning: A Literature Review and Analysis of the Work of Coase.The Town Planning Review, 65(1), pp.77-98.

Leishman, C. \& Rowley, S., 2012. Affordable Housing. In D. F. Clapham, W. A. Clark, \& K. (Eds) Gibb, eds. The Sage Handbook of Housing Studies. London: Sage, pp. 379396.

Lens, M. C. \& Monkkonen, P., 2015. Do Strict Land Use Regulations Make Metropolitan Areas More Segregated by Income? Journal of the American Planning Association, 82(1), pp.6-21.

Malpezzi, S. \& Mayo, S. K., 1997. Getting Housing Incentives Right: A Case Study of the Effects of Regulation, Taxes, and Subsidies on Housing Supply in Malaysia, Land Economics. 73(3), pp.372-391.

Manirakiza, V., 2012. Urbanization Issue in the Era of Globalization: Perspectives for Urban Planning in Kigali. In 4th Annual Conference on Social Studies for Community Cohesion and Sustainable Development. Kigali, pp. 1-19.

Manirakiza, V., 2014. Promoting Inclusive Approaches to Address Urbanization Challenges in Kigali. African Review of Economics and Finance, Vol 6, No 1.

Mathema, A., 2012. Addressing Affordable Housing in a Modernizing City: The Rwanda Experience. In Sixth Urban Research and Knowledge Symposium. DC: World Bank.

Mayer, C. J. \& Somerville, C. T., 2000. Land Use Regulation and New Construction. 30, pp.639-662.

Mayo, S. K. \& Angel, S., 1993. Housing: Enabling Markets to Work., Washington, DC.

Megbolugbe, I. F., Marks, A. P., \& Schwartz, M. B., 1991. The Economic Theory of Housing Demand: A Critical Review. Journal of Real Estate Research 6, no. 3: 381-93. 
MININFRA, 2015. National Housing Policy. National Housing Policy. pp.1-50.

Molina-Azorin, J. F. (2011). The Use and Added Value of Mixed Methods in Management Research. Journal of Mixed Methods Research, 5(1), 7-24.

Monkkonen, P., 2013. Urban Land-Use Regulations and Housing Markets in Developing Countries: Evidence from Indonesia on the Importance of Enforcement. Land Use Policy, 34, pp.255-264.

Morse, J. M., \& Chung, S. E. (2003). Toward Holism: The Significance of Methodological Pluralism. International Journal of Qualitative Methods, 2(3), 1-12.

Nasr, J. \& Volait, M., 2003. Urbanism: Imported or Exported? Chichester: Wiley-Academy.

Nduka, E. C., \& Kalu, I. E., 1986. Economic Analysis of Waste Management in Nigeria. Journal of Applied Sciences and Environmental Management, Vol. 6, No. 1, June, 2002, pp. 64-68.

Nduwayezu, G., 2015. Modeling Urban Growth in Kigali City Rwanda. University of Twente.

Ngoboka, I., 2015. City Mayor Calls for Optimum Land Use in Kigali. The New Times. Available at: http://www.newtimes.co.rw/section/article/2015-02-11/185866/ (Accessed on June 10, 2016).

NISR, 2016a. Labor Force Survey 2016. Kigali.

NISR, 2016b. Rwanda Integrated Household Living Conditions Survey (EICV) 2013/2014. Kigali.

Njiru, M. M., \& Moronge, M., 2013. Factors Affecting Growth of Mortgage Industries in Kenya: A Case Study of National Housing Corporation. International Journal of Social Sciences and Entrepreneurship. 1 (7), 26-35.

Njoh, A. J., 1995. Building and Urban Land-Use Controls in Developing-Countries - a CriticalAppraisal of the Kumba (Cameroon) Zoning-Ordinance. Third World Planning Review, 17(3), pp.337-356.

Njoh, A. J., 2003. Planning in Contemporary Africa: The State, Town Planning and Society in Cameroon. Hampshire: Ashgate Publishing Limited.

Nkurunziza, J. D., Ndikumana, L., \& Nyamoya, P., 2016. The Financial Sector in Burundi: An Investigation of Its Efficiency in Resource Mobilization and Allocation. In African Successes. Volume III: Modernization and Development. (p. 103 - 156). University of Chicago Press.

Nubi, O. T., 2008. Affordable Housing Delivery in Nigeria. The South African Foundation International Conference and Exhibition, Cape Town, pp 1- 18.

Okpala, D., 2009. Regional Overview of the Status of Urban Planning and Planning Practice in Anglophone (Sub-Saharan) African Countries. Ibadan.

OZ Architecture, 2007. Kigali Conceptual Master Plan. Kigali.

Planet Consortium, 2012. Housing Market Demand, Housing Finance and Housing Preferences for the City of Kigali.

Potter, J. \& Wetherell, M., 1994. Analyzing Discourse. In A. Bryman \& R. G. Burgess, eds. Analyzing Qualitative Data. London: Routledge.

Quigley, J. M. \& Raphael, S., 2004. Is Housing Unaffordable? Why Isn't it More Affordable? Trends in the Rental and Owner-Occupied Housing Markets: The Past 40 Years. Journal of Economic Perspectives-Volume, 18(1-Winter), pp.191-214.

Quigley, J. M., 2007. Regulation and Property Values in the United States: The High Cost of Monopoly. pp.46-67.

REMA, 2013. Kigali State of Environment and Outlook Report 2013. Kigali. 
Republic of Rwanda, 2010. Law No 15/2010 of 07/05/2010 creating and organizing condominiums and procedures for their registration, Kigali, Rwanda: Official Gazette $n^{\circ}$ special of 14/05/2010.

Republic of Rwanda, 2012. Law No 24/2012 of 15/06/2012 relating to the planning of land use and development in Rwanda, Kigali, Rwanda: Official Gazette $n^{\circ} 31$ of $30 / 07 / 2012$.

Republic of Rwanda, 2013. Law No 43/2013 of 16/06/2013 governing land in Rwanda, Kigali, Rwanda: Official Gazette no Special of 16/06/2013.

Republic of Rwanda, 2015a. Law No 32/2015 OF 11/06/2015 Relating to expropriation in the public interest, Kigali: Official Gazette no 35 of 31/08/2015.

Republic of Rwanda, 2015b. The Law on Investment Promotion and Facilitation, Kigali, Rwanda: Official Gazette no Special of 27/05/2015.

Rosen, W. J., 2015. In Push to Modernize, Rwandan Capital Struggles to House its Population. Al Jazeera.

Sharma, M., 2012. Remaking Kigali: A 21st Century Rwanda Built by Rwandans. Available at: http://matadornetwork.com/abroad/remaking-kigali-a-21st-century-rwanda-builtby-rwandans/ (Accessed June 12, 2018).

Shatkin, G., 2014. Reinterpreting the Meaning of the 'Singapore Model': State Capitalism and Urban Planning. International Journal of Urban and Regional Research, 38(1), pp.116-137.

Sivam, A., 2002. Constraints Affecting the Efficiency of the Urban Residential Land Market in Developing Countries: A Case Study of India. Habitat International, 26, 523-537.

Smets, P., Bredenoord, J. \& Van Lindert, P., 2014 (eds). Affordable Housing in the Urban Global South. London: Routledge.

Stone, M. E., 2006. What is Housing Affordability? The Case for the Residual Income Approach. Housing Policy Debate, 17(1), pp.151-184.

Symposium, 2007. Urban Land Use and Land Markets. Washington, DC: The World Bank, pp. 1689-1699.

Tashakkori, A., \& Teddlie, C. (2008). Introduction to Mixed Method and Mixed Model Studies in the Social and Behavioral Science. In V.L. Plano-Clark \& J. W. Creswell (Eds.), The mixed methods reader, (pp. 7-26).

UN-Habitat, 2008. Housing Finance Mechanisms in Thailand. United Nations Human

Settlement Programme, Naroibi.p.45-57. Available at: www.unhabitat.org (Accessed July 10, 2018).

UN-Habitat, 2009. Global Report on Human Settlement 2009: Planning Sustainable Cities. Nairobi.

UN-Habitat, 2011. Affordable Land and Housing in Africa. Nairobi.

UN-Habitat, 2013. The State of the World's Cities: Prosperity of Cities. New York.

UN-Habitat, 2016. World Cities Report 2016. Nairobi.

Viitanen, K., 2002. Just Compensation in Expropriation? FIG XXII International Congress

Washington D.C. Available at:

https://www.fig.net/resources/proceedings/fig_proceedings/fig_2002/Js26/JS26_v iitanen.pdf (Accessed on August, 2017)

Watson, V., 2009a. Seeing from the South: Refocusing Urban Planning on the Globe's Central Urban Issues. Urban Studies, 46(11), pp.2259-2275. 
Watson, V., 2009b. 'The Planned City Sweeps the Poor Away...': Urban Planning and 22st Century Urbanization. Progress in Planning, 72(3), pp.151-193.

Whitehead, C. M., 2007. Planning Policies and Affordable Housing: England as a Successful Case Study. Housing Studies, 12(4), pp.291-317.

Woetzel, J., Ram, S., Mischke, J., Garemo, N., \& Sankhe S., 2014. A Blueprint for Addressing the Global Affordable Housing Challenge. San Francisco.

World Bank, 2012. Informal Housing: Reducing Disaster Vulnerability Through Safer Construction. Kigali.

World Bank, 2015. Rwanda Poverty Assessment. Kigali.

Yuen, B., 2007. Guiding Spatial Changes: Singapore Urban Planning. In 4th Urban Research. 